\title{
Expanded mitochondrial control region sequences increase resolution of stock structure among North Atlantic loggerhead turtle rookeries
}

\author{
Brian M. Shamblin ${ }^{1, *}$, Alan B. Bolten, Karen A. Bjorndal, Peter H. Dutton, \\ Janne T. Nielsen, F. Alberto Abreu-Grobois, Kimberly J. Reich, Blair E. Witherington, \\ Dean A. Bagley, Llewellyn M. Ehrhart, Anton D. Tucker, David S. Addison, \\ Alejandro Arenas, Chris Johnson, Raymond R. Carthy, Margaret M. Lamont, \\ Mark G. Dodd, Michael S. Gaines, Erin LaCasella, Campbell J. Nairn
}

${ }^{1}$ Daniel B. Warnell School of Forestry and Natural Resources, University of Georgia, Athens, Georgia 30602, USA

\begin{abstract}
The southeastern USA hosts the largest nesting concentration of loggerhead turtles Caretta caretta in the Atlantic. Regionally significant nesting also occurs along the Caribbean coast of Mexico, in Cuba, and in the Bahamas. Previous studies of North Atlantic loggerhead turtle rookeries based on a $380 \mathrm{bp}$ fragment of the mitochondrial control region supported recognition of 8 demographically independent nesting populations (management units) in the Northwest Atlantic in addition to Cape Verde in the eastern Atlantic. Recent analysis of expanded mitochondrial control region sequences revealed additional genetic diversity and increased population structure between western and eastern Atlantic loggerhead turtle rookeries. We sequenced an 817 bp mitochondrial DNA fragment in 2427 samples from nesting beaches in the southeastern USA, Cay Sal Bank, Bahamas, and Quintana Roo, Mexico. Pairwise $F_{\mathrm{ST}}$ comparisons, pairwise exact tests of population differentiation, and analysis of molecular variance support previously proposed management unit designations and additionally indicate that southeastern and southwestern Florida rookeries should be recognized as distinct management units. Therefore, Northwest Atlantic loggerhead turtle rookeries can be subdivided into 10 management units, corresponding to the beaches from (1) Virginia through northeastern Florida, (2) central eastern Florida, (3) southeastern Florida, (4) Dry Tortugas, Florida, (5) Cay Sal, Bahamas, (6) southwestern Cuba, (7) Quintana Roo, Mexico, (8) southwestern Florida, (9) central western Florida, and (10) northwestern Florida. We confirmed increased resolution of stock structure between many Northwest Atlantic management units and the Cape Verde rookery with the expanded control region haplotypes.
\end{abstract}

KEY WORDS: Population genetic structure $\cdot$ Marine turtles $\cdot$ Caretta caretta $\cdot$ Mitochondrial DNA

\section{INTRODUCTION}

Defining genetic structure of marine species with high dispersal capability is complicated by the absence of apparent physical barriers across large spatial scales. For marine turtles, natal philopatry to specific nesting sites delimits population boundaries (reviewed by Bowen \& Karl 2007), and these nesting populations are self-contained demographic units over short ecological time scales. Evidence suggests that breeding salmon and marine turtles locate natal regions through a biphasic navigation process that initially uses magnetic cues to direct long distance ocean migration to the general vicinity of the natal area (Lohmann et al. 2008b). Benhamou et al. (2011) hypothesized that the process is even more complex with a magnetic component comprising the second phase of a 3-step process and operating only at intermediate scales of $10 \mathrm{~s}$ of $\mathrm{km}$. Several cues have been hypothesized to contribute to island finding and the 
final step of fine scale nesting beach selection in marine turtles (Lohmann et al. 2008a,b, Benhamou et al. 2011), but the relative importance of these factors and perhaps additional mechanisms remains unclear. The precise scale of natal homing in marine turtles may vary across populations as well as among species (reviewed by Bowen \& Karl 2007). Rookeries flourish or perish based on recruitment and survival of females (Bowen et al. 2005); therefore, determining the scale of female natal homing in marine turtle populations is essential for population monitoring and management on ecological time scales. Marine turtle researchers from around the globe have highlighted the characterization of rookery and foraging ground connectivity and partitioning as a major priority for conservation planning (Hamann et al. 2010).

Loggerhead turtles are distributed in warm temperate waters circumglobally (Bolten 2003). The 2 largest nesting aggregations occur in the southeastern United States of America (USA) and Masirah, Oman (Dodd 1988, Baldwin et al. 2003). In the southeastern USA, loggerhead turtles nest regularly where suitable sandy beaches occur from Virginia to Texas. Nesting densities vary considerably along this coastline with 6 counties in eastern Florida accounting for approximately $80 \%$ of nesting effort for the species nationally (NMFS \& USFWS 2008). Annual mean nest numbers on Florida's index nesting beaches declined by approximately $44 \%$ from 1998 through 2006 (Witherington et al. 2009), prompting concern that the largest nesting population in the Atlantic may be in decline. In addition to the southeastern USA, the Caribbean coast of Mexico, Cay Sal Bank (Bahamas), and the beaches of southwestern Cuba also serve as important nesting habitats in the Northwest Atlantic, hosting hundreds to several thousands of nests each year (NMFS \& USFWS 2008).

Several demographically discrete nesting populations (management units) for loggerhead turtles in the Atlantic and Mediterranean basins have been detected based on frequency analysis of $380 \mathrm{bp}$ mitochondrial control region haplotypes (Fig. 1). Genetic structure at regional scales has been detected in the Northwest Atlantic, Brazilian, and Mediterranean nesting aggregations (Encalada et al. 1998, Bowen et al. 2004, Carreras et al. 2007, Ruiz et al. 2008, Garofalo et al. 2009, Reis et al. 2010, Shamblin et al. 2011a) but not among females nesting on various Cape Verde Islands (Monzón-Argüello et al. 2010). Early restriction fragment length polymorphism analyses determined that at least 2 genetic stocks occurred in the southeastern USA, one nesting on
Florida beaches and the other nesting on Georgia and South Carolina beaches (Bowen et al. 1993, 1994). More extensive sampling and sequence analysis of a $380 \mathrm{bp}$ portion of the mitochondrial control region added the northwestern Florida and Quintana Roo, (Mexico) rookeries as a distinct management unit (Encalada et al. 1998) followed by recognition of the Dry Tortugas as a distinct management unit (Pearce 2001). A recent analysis revealed additional structure within peninsular Florida, such that 6 management units were proposed for the southeastern USA, corresponding to the beaches from (1) Virginia through the Ponce Inlet area of northeastern Florida, (2) central eastern Florida, encompassing Volusia County south of Ponce Inlet and Brevard County, (3) southern Florida, represented by peninsular Florida beaches from Juno Beach in southeastern Florida through Keewaydin Island in southwestern Florida, (4) the Dry Tortugas, (5) central western Florida, represented by Sarasota County, and (6) northwestern Florida (Shamblin et al. 2011a).

Extensive haplotype sharing (based on 380 bp haplotypes) among loggerhead turtle rookeries occurs across regional and ocean basin scales with just 2 common haplotypes accounting for approximately $90 \%$ of samples from North Atlantic and Mediterranean loggerhead rookeries ( $n=1971$, Fig. 1). Overlap of mtDNA markers not only confounds assessments of demographic connectivity among some rookeries but also introduces uncertainty into estimates of rookery contributions to mixed aggregations of foraging turtles (Bolker et al. 2007). As rookery sampling effort has increased, additional haplotype sharing among regions has been detected that could affect interpretations of mixed stock analyses. For example, some portion of CC-A1 turtles foraging in the Mediterranean initially assigned to western Atlantic stocks (Laurent et al. 1998, Carreras et al. 2006) could originate from the proximal Cape Verde rookery.

Sequence comparisons of an expanded mtDNA control region fragment have detected novel polymorphism with the potential to improve hawksbill turtle population structure assessments and mixed stock analyses (Abreu-Grobois et al. 2006). Sequence analysis of approximately $760 \mathrm{bp}$ of the loggerhead turtle control region using the novel primers described in that study subdivided the common 380 bp haplotype CC-A1 into 4 haplotypes with the longer sequences, with each present only in the Cape Verde rookery or in the western Atlantic rookery sampled at Blackbeard Island, Georgia, USA (Monzón-Argüello et al. 2010). These results are promising, and additional data are needed from the 
major Atlantic rookeries to evaluate the utility of the expanded control region sequences to improve resolution of population structure and mixed stock analyses. We addressed this need through reassessment of population structure among North Atlantic loggerhead turtle rookeries using the $817 \mathrm{bp}$ control region fragment. This analysis also substantially increased sample sizes compared with previous studies for most sampled populations and added novel haplotype data from the Cay Sal Bank rookery, the largest nesting population in the Bahamas (Addison \& Mumford 1996, Dow et al. 2007).

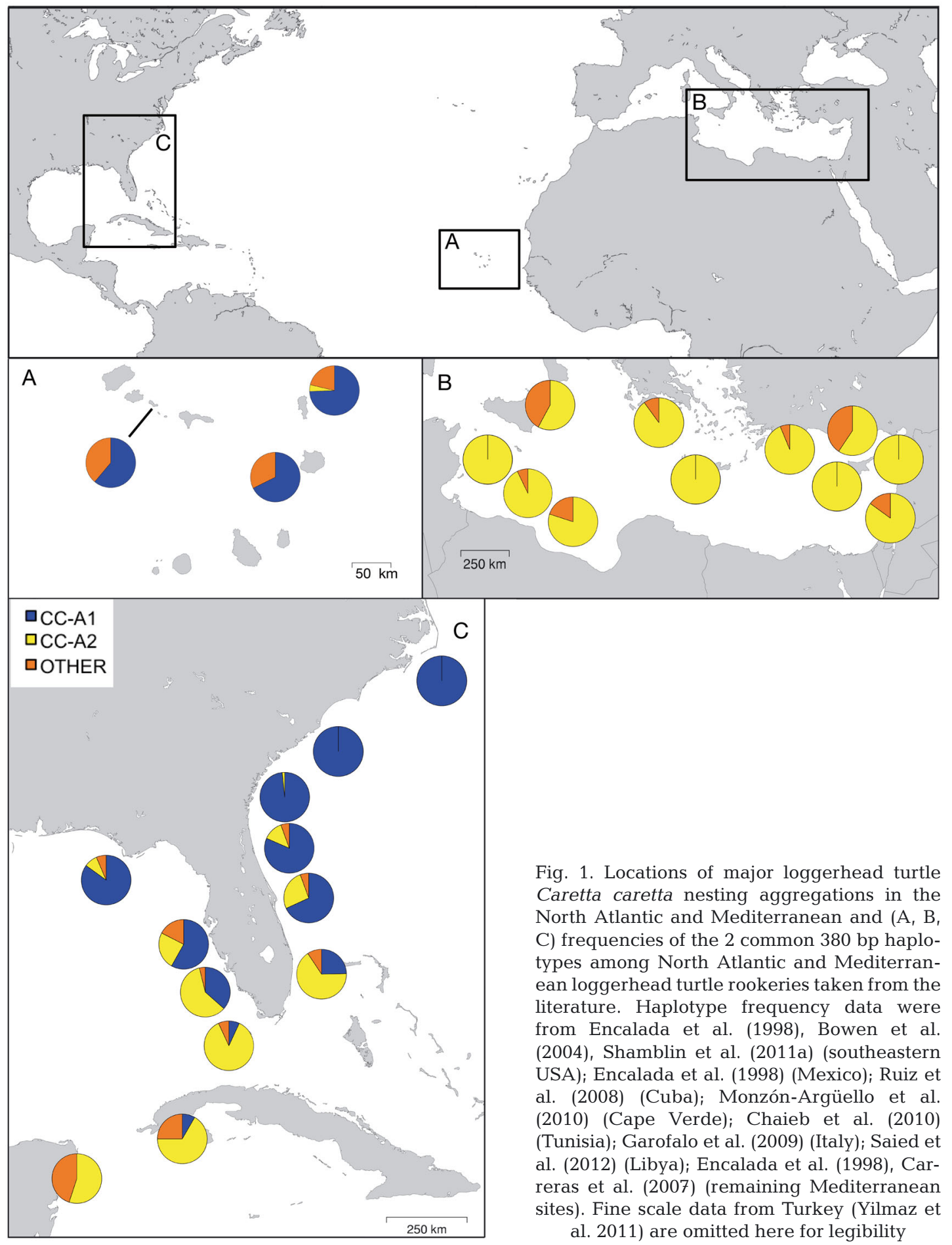




\section{MATERIALS AND METHODS}

\section{Field methods}

Samples from 2427 individual loggerhead turtles or nests were collected from 12 southeastern USA beach locations, several beaches on Isla Cozumel (Mezcalitos, Punta Morena, Antiguo Hotel Alegro, Chen Río, San Martín, Buenavista, Punta Chiqueros, and Box) and the mainland of Quintana Roo, Mexico (Paamul, Aventuras-DIF, Chemuyil, Xcacel, XelHa, Punta Cadena, Tankah, Kanzul, Cahpechen, and Lirios Balandrin), and Cay Sal Bank, Bahamas from the 1999 through 2010 nesting seasons (rookery codes and sampling years are defined in Table 1). Several samples were previously analyzed using the 380 bp haplotypes. DRT samples were a subset of those previously analyzed by Bowen et al. (2004). The 2002 to 2005 CSB and 2006 CAP, CAN, MEL, JUN, FTL, KEY, and CSK samples were those analyzed by Shamblin et al. (2011a). Sample sites were chosen to represent the extent of loggerhead turtle nesting in the USA and Quintana Roo where nesting densities were sufficient to provide adequate sample sizes and the Bahamian beach with the highest nesting density. Most rookeries are represented by skin samples that were collected from the shoulder region or rear flippers of nesting females following oviposition using $4 \mathrm{~mm}$ or $6 \mathrm{~mm}$ biopsy punches (Dutton 1996). Precautions were taken to ensure that each nesting female was represented only once, as determined by tagging or by microsatellite genotyping. Genotyping utilized 15 loci and had a minimum nonexclusion probability of identity of $2.07 \times 10^{-24}$ (Shamblin et al. 2007, 2009). OSS samples were eggshells collected within $12 \mathrm{~h}$ of oviposition and genotyped at 15 or 17 loci to assign individual identity (DNA extraction and sample assignment methods detailed in Shamblin et al. 2011b). Nest samples were dead hatchlings or hatched eggshells collected during post-emergence nest evaluations or blood samples from live hatchlings, and each nest was represented by a single sample. A 10 d sampling window was chosen to maximize sample sizes while minimizing the probability of re-sampling females. The average inter-nesting interval for southeastern USA loggerhead turtles is approximately $14 \mathrm{~d}$, with females rarely re-nesting at fewer than $11 \mathrm{~d}$ (reviewed in Dodd 1988). As FTL samples were from tagged females and clutches laid by unknown females, all were genotyped and analyzed for parentage at a minimum of 6 loci to remove duplicate samples from individual females. Samples were stored in $70 \%$ ethanol, $95 \%$ ethanol, or saturated $\mathrm{NaCl}-\mathrm{DMSO}$ buffer prior to DNA extraction.

\section{Laboratory methods}

Genomic DNA was extracted using a standard phenol-chloroform isolation or the DNeasy blood and tissue kit (QIAGEN) following standard protocols for tissue and with modifications previously described for egg shells (Shamblin et al. 2011b). Polymerase chain reaction (PCR) amplifications of an $817 \mathrm{bp}$ fragment of the mitochondrial control region were carried out using primers LCM15382 and H950g (Abreu-Grobois et al. 2006). PCR reactions were carried out in $20 \mu \mathrm{l}$ volumes containing $10 \mathrm{mM}$ Tris, $\mathrm{pH} 8.4,50 \mathrm{mM} \mathrm{KCl}, 0.5 \mu \mathrm{M}$ of each primer, $1.5 \mathrm{mM} \mathrm{MgCl}_{2}, 0.2 \mathrm{mM}$ dNTPs, 0.5 unit of Taq DNA polymerase, and approximately 10 to $30 \mathrm{ng}$ of genomic DNA. PCR cycling parameters were as follows: $95^{\circ} \mathrm{C}$ for $3 \mathrm{~min}$; 35 cycles of $95^{\circ} \mathrm{C}$ for $30 \mathrm{~s}, 55^{\circ} \mathrm{C}$ for $60 \mathrm{~s}, 72^{\circ} \mathrm{C}$ for $30 \mathrm{~s}$; and a final extension of $72^{\circ} \mathrm{C}$ for $10 \mathrm{~min}$. PCR products were purified by adding $2 \mu$ l of ExoSAP-IT ${ }^{\circledR}$ (USB Corporation) to $7 \mu \mathrm{l}$ of the $\mathrm{PCR}$ reaction and incubated according to manufacturer's instructions. The mtDNA amplicons were sequenced using ABI BigDye v3.1 (PE Applied Biosystems) and an ABI $3130 x 1$ or $3730 x 1$ DNA Analyzer with LCM15382 and H950g. Samples processed at the University of Georgia were sequenced using LCM15382 and an internal sequencing primer CC443 (TGA TCT ATT CTG GCC TCT G). Negative controls were included in each batch of PCR amplifications and sequencing reactions to detect contamination.

\section{Data analysis}

Sequences were aligned, edited, and compared to previously described haplotypes using the program Sequencher 4.2 (Gene Codes Corporation). Sequences were assigned haplotype designations after nomenclature published on the Archie Carr Center for Sea Turtle Research (ACCSTR) website (http://accstr.ufl. edu/accstr-resources/cclongmtdna.pdf). Original, short haplotypes received consecutive number designations based on the $380 \mathrm{bp}$ sequence. Haplotypes based on the $817 \mathrm{bp}$ fragment retained their original $380 \mathrm{bp}$ designations and received additional numeral suffixes to reflect any novel polymorphisms detected within the expanded sequences. Samples producing novel or ambiguous sequences were subjected to a 
Table 1. Sample collection and nesting data for sampled rookeries. Nests are annual mean nest counts from 2002 to 2006 unless otherwise noted. F samples were skin biopsies obtained from nesting females. E samples were eggs collected the morning following oviposition. N samples were either blood samples collected from hatchlings or dead hatchling or hatched egg shells collected during post-emergence nest evaluations

\begin{tabular}{|c|c|c|c|c|c|c|}
\hline Code & Sample beach & Nests & Years sampled & Samples & Type & Source \\
\hline CAP & Cape Island, South Carolina, USA & $735^{\mathrm{a}}$ & 2006 & 52 & $\mathrm{~F}$ & Shamblin et al. (2011a) \\
\hline OSS & Ossabaw Island, Georgia, USA & $165^{\mathrm{b}}$ & $\begin{array}{l}2008 \\
2009\end{array}$ & $\begin{array}{l}58 \\
31\end{array}$ & $\begin{array}{l}E \\
E\end{array}$ & $\begin{array}{l}\text { Present study } \\
\text { Present study }\end{array}$ \\
\hline CAN & Canaveral National Seashore, Florida, USA & $2738^{\mathrm{C}}$ & $\begin{array}{l}2001 \\
2003 \\
2004 \\
2006\end{array}$ & $\begin{array}{c}156 \\
52 \\
48 \\
58\end{array}$ & $\begin{array}{l}F \\
F \\
F \\
F\end{array}$ & $\begin{array}{l}\text { Present study } \\
\text { Present study } \\
\text { Present study } \\
\text { Shamblin et al. (2011a) }\end{array}$ \\
\hline MEL & Melbourne Beach, Florida, USA & $9439^{c}$ & $\begin{array}{l}2003 \\
2004 \\
2006 \\
2007 \\
2008\end{array}$ & $\begin{array}{l}201 \\
147 \\
104 \\
132 \\
166\end{array}$ & $\begin{array}{l}F \\
F \\
F \\
F \\
F\end{array}$ & $\begin{array}{l}\text { Present study } \\
\text { Present study } \\
\text { Shamblin et al. (2011a) } \\
\text { Present study } \\
\text { Present study }\end{array}$ \\
\hline JUN & Juno Beach, Florida, USA & $3136^{\mathrm{c}}$ & $\begin{array}{l}2003 \\
2004 \\
2006\end{array}$ & $\begin{array}{l}52 \\
41 \\
48\end{array}$ & $\begin{array}{l}\mathrm{F} \\
\mathrm{F} \\
\mathrm{F}\end{array}$ & $\begin{array}{l}\text { Present study } \\
\text { Present study } \\
\text { Shamblin et al. (2011a) }\end{array}$ \\
\hline FTL & Ft. Lauderdale, Florida, USA & $575^{\mathrm{c}}$ & $\begin{array}{l}2003 \\
2006\end{array}$ & $\begin{array}{l}46 \\
29\end{array}$ & $\begin{array}{l}\mathrm{F} \\
\mathrm{N}\end{array}$ & $\begin{array}{l}\text { Present study } \\
\text { Shamblin et al. (2011a) }\end{array}$ \\
\hline CSL & Cay Sal Bank, Bahamas & $100-500^{\mathrm{d}}$ & $\begin{array}{l}1999 \\
2000\end{array}$ & $\begin{array}{c}6 \\
15\end{array}$ & $\begin{array}{l}\mathrm{F} \\
\mathrm{F}\end{array}$ & $\begin{array}{l}\text { Present study } \\
\text { Present study }\end{array}$ \\
\hline DRT & Dry Tortugas, Florida, USA & $151^{\mathrm{c}, \mathrm{e}}$ & 1998 & 32 & $\mathrm{~N}$ & Bowen et al. (2004) \\
\hline ICZ & Isla Cozumel, Quintana Roo, Mexico & $230^{\mathrm{f}}$ & 2008 & 21 & $\mathrm{~N}$ & Present study \\
\hline QRM & Mainland Quintana Roo beaches, Mexico & $1218^{g}$ & $\begin{array}{l}2006 \\
2008\end{array}$ & $\begin{array}{l}99 \\
56\end{array}$ & $\begin{array}{l}\mathrm{F} \\
\mathrm{F}\end{array}$ & $\begin{array}{l}\text { Present study } \\
\text { Present study }\end{array}$ \\
\hline KEY & Keewaydin Island, Florida, USA & $128^{\mathrm{c}}$ & $\begin{array}{l}2004 \\
2006 \\
2007 \\
2008 \\
2009 \\
2010\end{array}$ & $\begin{array}{l}37 \\
39 \\
29 \\
49 \\
22 \\
32\end{array}$ & $\begin{array}{l}\text { F } \\
\text { F } \\
\text { F } \\
\text { F } \\
\text { F } \\
\text { F }\end{array}$ & $\begin{array}{l}\text { Present study } \\
\text { Shamblin et al. (2011a) } \\
\text { Present study } \\
\text { Present study } \\
\text { Present study } \\
\text { Present study }\end{array}$ \\
\hline CSK & Casey Key, Florida, USA & $449^{c}$ & $\begin{array}{l}2006 \\
2007 \\
2008 \\
2009 \\
2010\end{array}$ & $\begin{array}{c}55 \\
64 \\
100 \\
90 \\
148\end{array}$ & $\begin{array}{l}\text { F } \\
F \\
F \\
F \\
F\end{array}$ & $\begin{array}{l}\text { Shamblin et al. (2011a) } \\
\text { Present study } \\
\text { Present study } \\
\text { Present study } \\
\text { Present study }\end{array}$ \\
\hline SGI & St. George Island, Florida, USA & $106^{\mathrm{c}}$ & $\begin{array}{l}2007 \\
2008\end{array}$ & $\begin{array}{l}13 \\
12\end{array}$ & $\begin{array}{l}\mathrm{N} \\
\mathrm{N}\end{array}$ & $\begin{array}{l}\text { Present study } \\
\text { Present study }\end{array}$ \\
\hline CSB & Cape San Blas, Florida, USA & $36^{\mathrm{c}}$ & $\begin{array}{l}2002 \\
2003 \\
2004 \\
2005 \\
2010\end{array}$ & $\begin{array}{c}15 \\
14 \\
10 \\
9 \\
39\end{array}$ & $\begin{array}{l}F \\
F \\
F \\
F \\
F\end{array}$ & $\begin{array}{l}\text { Shamblin et al. (2011a) } \\
\text { Shamblin et al. (2011a) } \\
\text { Shamblin et al. (2011a) } \\
\text { Shamblin et al. (2011a) } \\
\text { Present study }\end{array}$ \\
\hline \multicolumn{7}{|c|}{$\begin{array}{l}\text { 'Statewide Nesting Beach Survey data, Florida Fish and Wildlife Research Institute, Florida Fish and Wildlife Conserva- } \\
\text { tion Commission } \\
\text { dBahamas data from Dow et al. (2007), numbers represent total crawls, not just nests } \\
\text { eNest counts available from } 2003 \text { and } 2004 \text { only } \\
\text { f2008 nest count from Rafael Chacón, Director de Ecología en el Municipio de Cozumel } \\
\text { gAverage nest count for } 2006 \text { and 2008; Flora, Fauna y Cultura de México, A.C. Programa de Protección y Conservación } \\
\text { de Tortugas Marinas en el Litoral Central del Estado de Quintana Roo data }\end{array}$} \\
\hline
\end{tabular}


second round of DNA extraction, PCR amplification, and sequencing for verification. Novel haplotypes were deposited with Genbank and ACCSTR. An unrooted parsimony network was created using the program TCS (Clement et al. 2000). Haplotype distribution maps were generated using the Maptool function at www.seaturtle.org/maptool/.

Haplotype diversity $(h)$, pairwise $F_{\mathrm{ST}}$ comparisons, and tests of genetic partitioning were conducted using the software Arlequin version 3.5 (Excoffier \& Lischer 2010). Significance values for analysis of molecular variance (AMOVA) were obtained from 10000 permutations. Tests of temporal variation of haplotype frequencies were conducted using haplotype frequency-based AMOVA. All interannual samples for each site that were not significantly different were pooled for spatial analyses. Spatial structure was examined using pairwise $F_{\mathrm{ST}}$ comparisons, exact tests of population differentiation, and haplotype frequency-based AMOVA with p-values less than 0.05 considered significant. Exact tests of population differentiation were conducted with 100000 permutations and 10000 dememorization steps after the method of Raymond \& Rousset (1995). Frequency data for $380 \mathrm{bp}$ haplotypes for southwestern Cuban (SWC) rookeries ( $\mathrm{n}=36$; Ruiz et al. 2008) were included to assess the relationship of the Cuban rookeries relative to others in the region. As only short sequences were available from $\mathrm{Cuba}$, the reported $F_{\mathrm{ST}}$ values from Cuban comparisons were generated from a separate analysis so that the differences between values generated from 380 and $817 \mathrm{bp}$ haplotype data for remaining rookeries could be attributed solely to differences in haplotype resolution. A Mantel test as implemented in Arlequin 3.5 was used to test for the presence of isolation by distance (Mantel 1967) based on the haplotype frequency-based $F_{\mathrm{ST}}$ matrix. These correlations were calculated using both straight-line distances and minimum swim distances to account for terrestrial barriers between sampling sites.

Following pairwise $F_{\mathrm{ST}}$ comparisons and exact tests of population differentiation, proximal Northwest Atlantic sample sites that were not significantly different using both tests were pooled for further analyses. Any ambiguous rookery clustering and splitting decisions were testing through alternative groupings by pairwise tests and AMOVA. Optimal groupings were considered to yield the highest values for $F_{\mathrm{ST}}$ and $F_{\mathrm{CT}}$, respectively, while also minimizing $F_{\mathrm{SC}}$ for AMOVA. To minimize bias in the case of incorrect pooling decisions, haplotype frequencies were weighted for each proposed management unit based on the relative size of individual rookeries comprising them as measured by nest counts. Haplotype frequencies from proposed Northwest Atlantic management units determined from the initial analysis were then compared with published data from Cape Verde ( $\mathrm{n}=128$; Monzón-Argüello et al. 2010). Significance of the final round of pairwise $F_{\mathrm{ST}}$ comparisons and exact tests of population differentiation were adjusted using sequential Bonferroni correction with a table-wide $\alpha$ of 0.05 (Rice 1989).

\section{RESULTS}

\section{Haplotypes}

Sequence alignments of the $380 \mathrm{bp}$ control region fragment revealed 34 polymorphic sites, corresponding to 26 transitions and 9 indels among the Northwest Atlantic sample set (see Table S1 in the supplement at www.int-res.com/articles/suppl/ m469p145_supp.xls). Position 358 contained both an indel and a transition. Sixteen of the polymorphic sites differed only between the 2 Atlantic lineages previously described from $380 \mathrm{bp}$ control region sequence analysis (Encalada et al. 1998). Polymorphic sites defined 22 haplotypes, 14 of which were previously described from Northwest Atlantic rookeries (Encalada et al. 1998, Bowen et al. 2004, Ruiz et al. 2008, Shamblin et al. 2011a). Haplotype CC-A21, formerly recovered from 2 foraging juveniles around the Straits of Gibraltar (Revelles et al. 2007), was found in 2 nesting females from CSK in the present study. Haplotype CC-A27, described from a juvenile foraging in the vicinity of the Gimnesies Islands in the western Mediterranean (Carreras et al. 2006), was recovered from a female nesting at CSB in northwestern Florida. The remaining haplotypes were novel: CC-A36, CC-A41, CC-A42, CC-A51, CC-A59, and CC-A60.

Sequence comparisons of the $817 \mathrm{bp}$ fragment yielded 22 additional polymorphic positions, corresponding to 20 transitions and 2 transversions (Table S1 in the supplement). Eleven of the sites varied only between the 2 lineages. Novel variable positions subdivided six 380 bp haplotypes into 18 variants for a total of 34 haplotypes resolved among Northwest Atlantic samples and 39 haplotypes across the North Atlantic with the expanded control region fragment (Fig. 2). Short haplotype CC-A1 was subdivided into 4 variants among Northwest Atlantic rookeries: CC-A1.1, CC-A1.2, CC-A1.3, and CCA1.4 (Fig. 3). Haplotypes CC-A1.3 and CC-A1.4 
were previously described from Cape Verde rookeries (Monzón-Argüello et al. 2010) and were found at low frequency in several Florida rookeries as well as in Quintana Roo, Mexico. CC-A1.1, formerly described from a Georgia rookery (Monzón-Argüello et al. 2010), was found at each USA rookery sampled but was absent from Cay Sal Bank, Bahamas and Quintana Roo, Mexico. CC-A1.2 was detected at low frequency along the eastern coast of Florida and at CSK. Short haplotype CC-A2 was subdivided into 6 variants: CC-A2.1, CC-A2.2, CC-A2.3, CC-A2.4, CCA2.5, and CC-A2.11. Haplotype CC-A2.1, previously reported from rookeries in Cape Verde, Italy, Turkey, and Libya (Garofalo et al. 2009, Monzón-Argüello et al. 2010, Yilmaz et al. 2011, Saied et al. 2012), was detected in all sampled Northwest Atlantic rookeries except CAP and OSS.

Haplotype diversity for 817 bp haplotypes varied from 0 to 0.819 (Table 2). Samples from the northernmost sampled rookeries (CAP and OSS) were fixed for a single haplotype. The 2 insular rookeries sampled in the eastern Gulf of Mexico (DRT and CSL) as well as the 2 northwestern Florida rookeries (SGI and CSB) exhibited the least haplotype diversity of any rookeries with multiple haplotypes, with values ranging from 0.236 to 0.288 . Peninsular Florida rookeries each had moderate haplotype

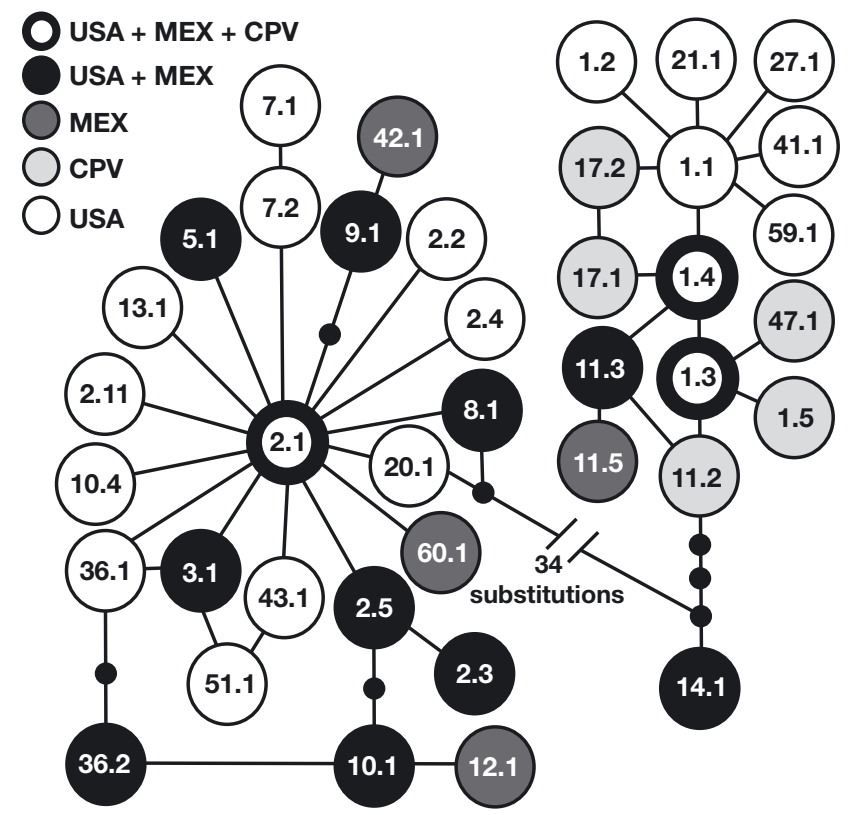

Fig. 2. Caretta caretta. Haplotype network depicting the 2 loggerhead turtle lineages nesting in the North Atlantic. Small filled circles indicate hypothetical haplotypes. USA is southeastern USA rookeries, data from present study. CPV is Cape Verde, data from Monzón-Argüello et al. (2010). MEX is Quintana Roo, Mexico rookeries, data from present study. Haplotypes CC-A2.1, CC-A3.1, CC-A13.1, CC-A20.1, and CC-A43.1 are also shared with Mediterranean rookeries (Garofalo et al. 2009, Yilmaz et al. 2011)

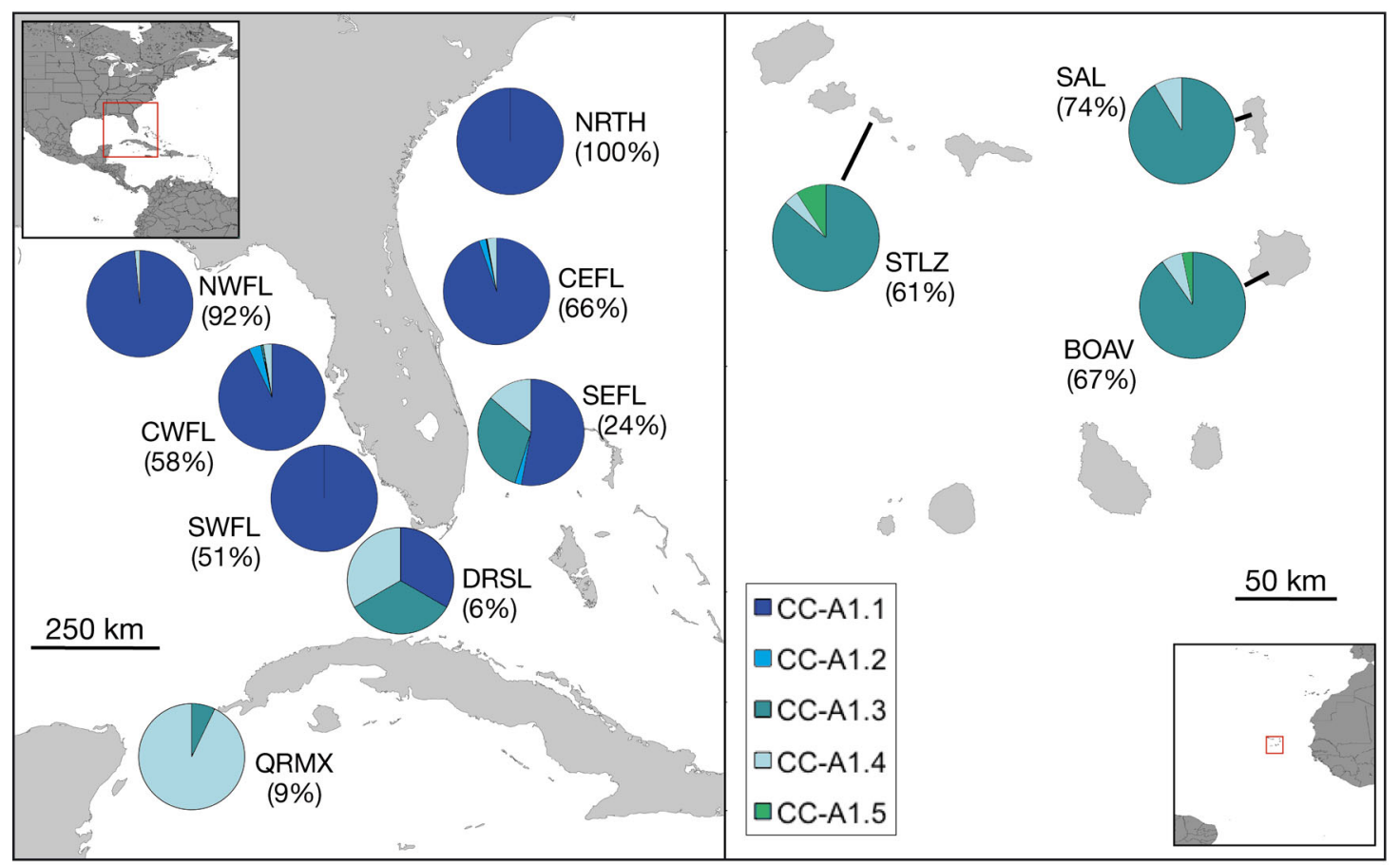

Fig. 3. Caretta caretta. Frequencies of $817 \mathrm{bp} \mathrm{CC-A1} \mathrm{variants} \mathrm{in} \mathrm{North} \mathrm{Atlantic} \mathrm{loggerhead} \mathrm{turtle} \mathrm{rookeries.} \mathrm{The} \mathrm{relative} \mathrm{fre-}$ quency of CC-A1 for each rookery or management unit is indicated in parentheses. Northwest Atlantic management unit abbreviations are explained in the text. Cape Verde data are from Monzón-Argüello et al. (2010). SAL: Island of Sal; STLZ: 
Table 2. Caretta caretta. Control region haplotype distribution for loggerhead turtle rookeries in the North Atlantic. Sample site codes for rookeries sampled in the present study are given in Table 1. N: total sample size. $h$ : haplotype diversity with standard deviation

\begin{tabular}{|c|c|c|c|c|c|c|c|c|c|c|c|c|c|c|c|}
\hline Haplotype & CAP & OSS & CAN & MEL & JUN & FTL & CSL & DRT & ICZ & QRM & KEY & CSK & SGI & CSB & $\mathrm{CPV}^{\mathrm{a}}$ \\
\hline CC-A1.1 & 52 & 89 & 210 & 458 & 20 & 7 & - & 1 & - & - & 106 & 248 & 21 & 73 & - \\
\hline CC-A1.2 & - & - & 3 & 12 & 1 & - & - & - & - & - & - & 9 & - & - & - \\
\hline CC-A1.3 & - & - & - & 3 & 8 & 8 & - & 1 & - & 1 & - & 2 & - & - & 79 \\
\hline CC-A1.4 & - & - & 8 & 12 & 6 & 1 & 1 & - & - & 13 & - & 7 & - & 2 & 6 \\
\hline CC-A1.5 & - & - & - & - & - & - & - & - & - & - & - & - & - & - & 3 \\
\hline CC-A2.1 & - & - & 78 & 197 & 76 & 47 & 18 & 28 & 11 & 53 & 80 & 108 & 3 & 9 & 2 \\
\hline CC-A2.2 & - & - & - & - & 1 & - & - & - & - & - & - & - & - & - & - \\
\hline CC-A2.3 & - & - & - & 1 & 3 & - & - & - & 1 & 5 & - & 2 & - & - & - \\
\hline CC-A2.4 & - & - & - & 1 & 2 & 6 & - & - & - & - & - & 3 & - & - & - \\
\hline CC-A2.5 & - & - & - & 1 & 1 & - & - & - & 1 & 9 & - & 3 & - & - & - \\
\hline CC-A2.11 & - & - & - & - & - & - & - & - & - & - & - & 1 & - & - & - \\
\hline CC-A3.1 & - & - & 7 & 30 & 10 & 4 & 1 & - & - & 3 & 13 & 46 & - & 1 & - \\
\hline CC-A5.1 & - & - & - & 2 & - & - & - & - & - & 2 & - & - & - & - & - \\
\hline CC-A7.1 & - & - & 2 & 5 & 2 & - & - & - & - & - & - & 6 & - & - & - \\
\hline CC-A7.2 & - & - & - & 2 & - & - & - & - & - & - & - & - & - & - & - \\
\hline CC-A8.1 & - & - & - & - & - & - & - & - & 1 & 6 & - & 1 & - & - & - \\
\hline CC-A9.1 & - & - & 1 & 1 & 2 & - & - & 2 & - & 8 & 1 & 1 & - & 1 & - \\
\hline CC-A10.1 & - & - & 1 & 8 & 5 & 2 & - & - & 6 & 35 & - & 7 & - & - & - \\
\hline CC-A10.4 & - & - & - & 1 & - & - & - & - & - & - & - & - & - & - & - \\
\hline CC-A11.2 & - & - & - & - & - & - & - & - & - & - & - & - & - & - & 1 \\
\hline CC-A11.3 & - & - & - & - & - & - & 1 & - & - & 7 & - & 1 & - & - & - \\
\hline CC-A11.5 & - & - & - & - & - & - & - & - & - & 1 & - & - & - & - & - \\
\hline CC-A12.1 & - & - & - & - & - & - & - & - & - & 2 & - & - & - & - & - \\
\hline CC-A13.1 & - & - & - & 1 & 1 & - & - & - & - & 2 & - & 2 & - & - & - \\
\hline CC-A14.1 & - & - & 3 & 12 & 1 & - & - & - & - & 7 & 1 & 5 & - & - & - \\
\hline CC-A17.1 & - & - & - & - & - & - & - & - & - & - & - & - & - & - & 27 \\
\hline CC-A17.2 & - & - & - & - & - & - & - & - & - & - & - & - & - & - & 6 \\
\hline CC-A20.1 & - & - & - & 2 & 2 & - & - & - & - & - & 5 & 1 & - & - & - \\
\hline CC-A21.1 & - & - & - & - & - & - & - & - & - & - & - & 2 & - & - & - \\
\hline CC-A27.1 & - & - & - & - & - & - & - & - & - & - & - & - & - & 1 & - \\
\hline CC-A36.1 & - & - & - & 1 & - & - & - & - & - & - & - & - & - & - & - \\
\hline CC-A36.2 & - & - & - & - & - & - & - & - & - & 1 & - & 1 & - & - & - \\
\hline CC-A41.1 & - & - & 1 & - & - & - & - & - & - & - & - & - & - & - & - \\
\hline CC-A42.1 & - & - & - & - & - & - & - & - & 1 & - & - & - & - & - & - \\
\hline CC-A43.1 & - & - & - & - & 1 & - & - & - & - & - & - & - & - & - & - \\
\hline CC-A47.1 & - & - & - & - & - & - & - & - & - & - & - & - & - & - & 1 \\
\hline CC-A51.1 & - & - & - & - & - & - & - & - & - & - & 2 & - & - & - & - \\
\hline CC-A59.1 & - & - & - & - & - & - & - & - & - & - & - & - & 1 & - & - \\
\hline CC-A60.1 & - & - & - & - & - & - & - & - & - & 1 & - & - & - & - & - \\
\hline $\mathrm{N}$ & 52 & 89 & 314 & 750 & 142 & 75 & 21 & 32 & 21 & 156 & 208 & 456 & 25 & 87 & 125 \\
\hline Haplotypes & 1 & 1 & 10 & 19 & 16 & 7 & 4 & 4 & 6 & 17 & 7 & 20 & 3 & 6 & 8 \\
\hline$h$ & $\begin{array}{c}0.000 \\
\pm \\
0.000\end{array}$ & $\begin{array}{c}0.000 \\
\pm \\
0.000\end{array}$ & $\begin{array}{c}0.491 \\
\pm \\
0.026\end{array}$ & $\begin{array}{c}0.555 \\
\pm \\
0.016\end{array}$ & $\begin{array}{c}0.686 \\
\pm \\
0.040\end{array}$ & $\begin{array}{c}0.585 \\
\pm \\
0.061\end{array}$ & $\begin{array}{c}0.271 \\
\pm \\
0.124\end{array}$ & $\begin{array}{c}0.236 \\
\pm \\
0.093\end{array}$ & $\begin{array}{c}0.667 \\
\pm \\
0.085\end{array}$ & $\begin{array}{c}0.819 \\
\pm \\
0.021\end{array}$ & $\begin{array}{c}0.591 \\
\pm \\
0.020\end{array}$ & $\begin{array}{c}0.638 \\
\pm \\
0.020\end{array}$ & $\begin{array}{c}0.290 \\
\pm \\
0.110\end{array}$ & $\begin{array}{c}0.288 \\
\pm \\
0.0610\end{array}$ & $\begin{array}{c}0.538 \\
\pm \\
0.044\end{array}$ \\
\hline
\end{tabular}

diversity, with values ranging from 0.491 to 0.686 . The highest haplotype diversity was recorded for the mainland Quintana Roo rookeries.

\section{Population structure}

Among AMOVA tests of interannual haplotype frequency differentiation, none yielded significant results (see Table S2 in the supplement); therefore, all interannual samples were pooled for spatial analysis. The 2 most common haplotypes, CC-A1.1 and CC-A2.1, accounted for approximately $82 \%$ of all individuals sampled in the Northwest Atlantic, but these haplotypes exhibited strong partitioning among sites (Fig. 4, Table 2). Of 120 pairwise comparisons among discrete Northwest Atlantic rookeries based on $380 \mathrm{bp}$ haplotypes, 108 pairwise $F_{\mathrm{ST}}$ 


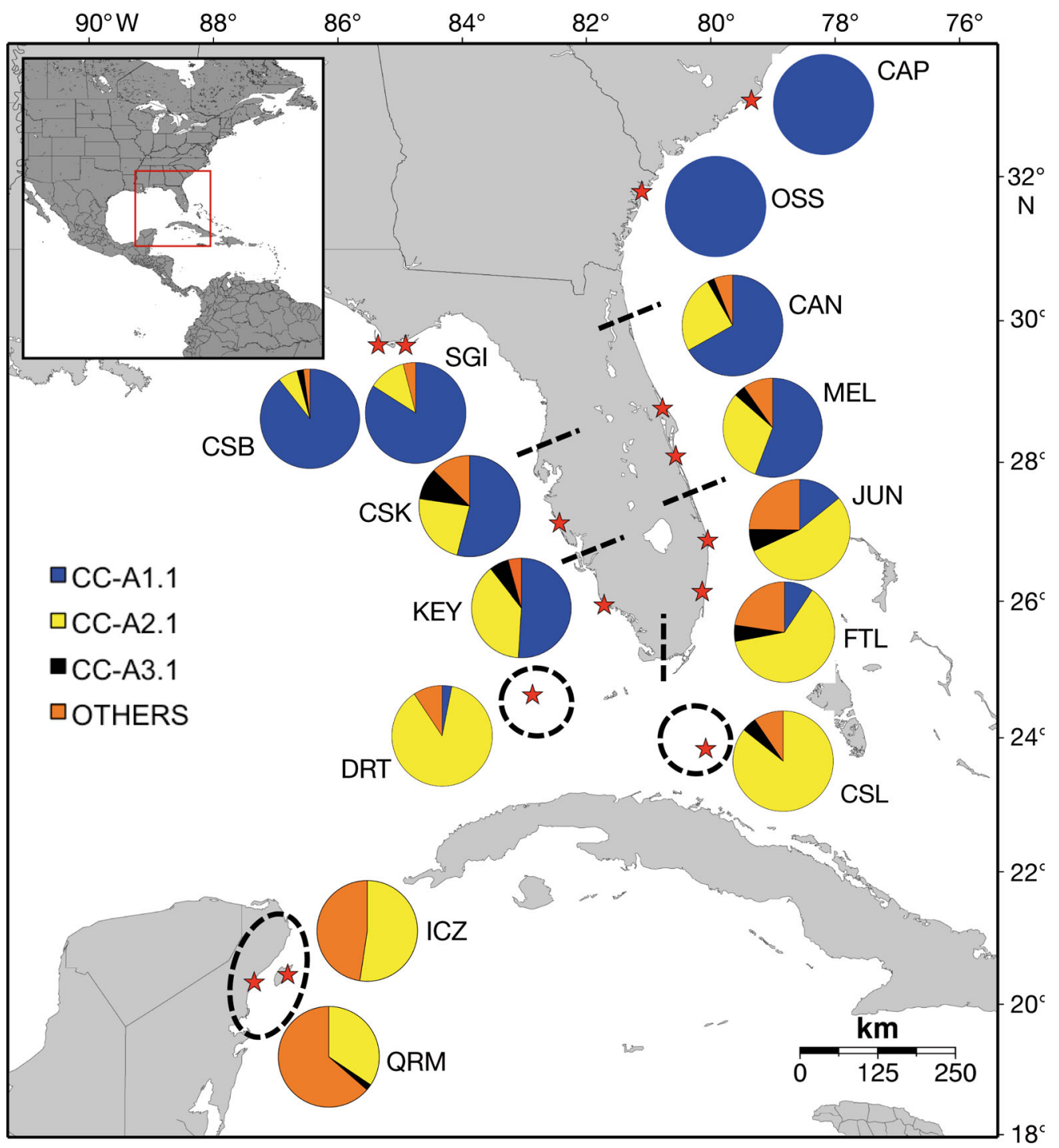

Fig. 4. Caretta caretta. Sample site locations and frequencies of the 3 most common haplotypes of sampled loggerhead turtle rookeries in the Northwest Atlantic. Rookery abbreviations are explained in Table 1. ( $\hbar$ ) Position of rookeries. Dashed lines: proposed management unit subdivisions but not necessarily precise placement of boundaries

comparisons and 107 exact tests of population differentiation indicated differentiation (Table 3, Table S3 in the supplement). Of 91 pairwise comparisons based on 817 bp haplotypes (less the Cuban rookery for which expanded sequences were not available), 84 pairwise $F_{\mathrm{ST}}$ comparisons and 79 exact tests of population differentiation were significant (Tables 3 \& S3). Comparisons involving proximal (ranging from 50 to approximately $270 \mathrm{~km}$ ) sample sites accounted for most of the nonsignificant differences.

Sample site clustering and splitting was generally unambiguous with appropriate boundaries indicated by congruent pairwise $F_{\mathrm{ST}}$ and exact tests of popula- tion differentiation. An exception was clustering for the rookeries of southeastern Florida, the Bahamas, and the eastern Gulf of Mexico: JUN, FTL, CSL, DRT, and SWC. Alternative pairwise clustering and AMOVA results clarified groupings for these rookeries (see Tables S4 \& S5, respectively, in the supplement). Partitioning among provisional management units previously proposed by the Recovery Plan for the Northwest Atlantic Population of the Loggerhead Sea Turtle (Caretta caretta) (NMFS \& USFWS 2008) and Shamblin et al. (2011a) was significant. Maximum $F_{\mathrm{CT}}$ was achieved by grouping Florida as proposed in the Recovery Plan. However, $F_{\mathrm{SC}}$ was also 
Table 3. Pairwise comparisons for Northwest Atlantic loggerhead turtle rookeries. Rookery abbreviations for present study sites are given in Table 1. CUB: Cuba. Pairwise $F_{\mathrm{ST}}$ values for $817 \mathrm{bp}$ haplotypes are above the diagonal. Pairwise $F_{\mathrm{ST}}$ values for $380 \mathrm{bp}$ haplotypes are below the diagonal. Nonsignificant differences $(\mathrm{p} \geq 0.05)$ are highlighted by gray shading

\begin{tabular}{|lllllllllllllllll|}
\hline & CAP & OSS & CAN & MEL & JUN & FTL & CSL & DRT & CUB & ICZ & QRM & KEY & CSK & SGI & CSB \\
\hline CAP & & 0.000 & 0.162 & 0.169 & 0.504 & 0.639 & 0.919 & 0.905 & - & 0.783 & 0.489 & 0.287 & 0.187 & 0.163 & 0.081 \\
OSS & 0.000 & & 0.179 & 0.179 & 0.549 & 0.697 & 0.945 & 0.933 & - & 0.846 & 0.530 & 0.318 & 0.200 & 0.236 & 0.108 \\
CAN & 0.156 & 0.173 & & 0.002 & 0.248 & 0.323 & 0.455 & 0.457 & - & 0.369 & 0.300 & 0.039 & 0.017 & 0.029 & 0.047 \\
MEL & 0.165 & 0.174 & 0.002 & & 0.204 & 0.268 & 0.390 & 0.392 & - & 0.309 & 0.266 & 0.020 & 0.006 & 0.047 & 0.064 \\
JUN & 0.509 & 0.554 & 0.246 & 0.198 & & 0.005 & 0.071 & 0.088 & - & 0.044 & 0.062 & 0.112 & 0.162 & 0.340 & 0.386 \\
FTL & 0.673 & 0.728 & 0.333 & 0.271 & 0.005 & & 0.047 & 0.062 & - & 0.062 & 0.092 & 0.170 & 0.224 & 0.441 & 0.497 \\
CSL & 0.915 & 0.942 & 0.474 & 0.405 & 0.074 & 0.032 & & -0.017 & - & 0.149 & 0.161 & 0.290 & 0.345 & 0.686 & 0.689 \\
DRT & 0.903 & 0.931 & 0.483 & 0.412 & 0.092 & 0.050 & -0.022 & & - & 0.188 & 0.186 & 0.296 & 0.352 & 0.700 & 0.694 \\
CUB & 0.750 & 0.812 & 0.388 & 0.324 & 0.378 & 0.031 & 0.043 & 0.065 & & - & - & - & - & - & - \\
ICZ & 0.823 & 0.876 & 0.435 & 0.370 & 0.080 & 0.093 & 0.117 & 0.154 & 0.057 & & 0.007 & 0.223 & 0.255 & 0.499 & 0.570 \\
QRM & 0.483 & 0.526 & 0.297 & 0.259 & 0.060 & 0.089 & 0.128 & 0.148 & 0.061 & 0.013 & & 0.192 & 0.211 & 0.346 & 0.393 \\
KEY & 0.287 & 0.318 & 0.052 & 0.028 & 0.080 & 0.141 & 0.267 & 0.283 & 0.191 & 0.242 & 0.150 & & 0.017 & 0.125 & 0.155 \\
CSK & 0.185 & 0.199 & 0.017 & 0.005 & 0.156 & 0.227 & 0.354 & 0.366 & 0.273 & 0.313 & 0.207 & 0.017 & & 0.066 & 0.084 \\
SGI & 0.163 & 0.236 & 0.021 & 0.039 & 0.333 & 0.464 & 0.672 & 0.692 & 0.501 & 0.550 & 0.333 & 0.125 & 0.060 & & -0.021 \\
CSB & 0.075 & 0.100 & 0.048 & 0.066 & 0.396 & 0.530 & 0.707 & 0.715 & 0.587 & 0.637 & 0.396 & 0.168 & 0.088 & -0.021 \\
\hline
\end{tabular}

Table 4. Pairwise comparisons for proposed loggerhead turtle management units in the North Atlantic. Management unit abbreviations are explained in the text. Pairwise $F_{\mathrm{ST}}$ values based on $817 \mathrm{bp}$ haplotypes are above the diagonal. Pairwise $F_{\mathrm{ST}}$ values based on $380 \mathrm{bp}$ haplotypes are below the diagonal. All comparisons were significant with table-wide $\alpha=0.05$ following sequential Bonferroni correction

\begin{tabular}{|lcccccccccc|}
\hline & NRTH & CEFL & SEFL & DRSL & SWCB & QRMX & SWFL & CWFL & NWFL & CPVD \\
\hline NRTH & & 0.180 & 0.561 & 0.927 & - & 0.566 & 0.356 & 0.213 & 0.126 & 0.728 \\
CEFL & 0.175 & & 0.215 & 0.401 & - & 0.275 & 0.022 & 0.007 & 0.062 & 0.442 \\
SEFL & 0.567 & 0.210 & & 0.088 & - & 0.066 & 0.115 & 0.172 & 0.385 & 0.345 \\
DRSL & 0.925 & 0.420 & 0.091 & & - & 0.190 & 0.309 & 0.365 & 0.693 & 0.546 \\
SWCB & 0.860 & 0.330 & 0.038 & 0.073 & & - & - & - & - & - \\
QRMX & 0.565 & 0.272 & 0.065 & 0.153 & 0.059 & & 0.190 & 0.215 & 0.400 & 0.296 \\
SWFL & 0.356 & 0.031 & 0.086 & 0.292 & 0.191 & 0.152 & & 0.020 & 0.157 & 0.418 \\
CWFL & 0.210 & 0.006 & 0.170 & 0.379 & 0.281 & 0.216 & 0.020 & 0.083 & 0.388 \\
NWFL & 0.123 & 0.058 & 0.385 & 0.693 & 0.576 & 0.396 & 0.163 & 0.079 & & 0.568 \\
CPVD & 0.288 & 0.123 & 0.364 & 0.604 & 0.484 & 0.350 & 0.185 & 0.118 & 0.127 & \\
\hline
\end{tabular}

significant under these scenarios (Table S5 in the supplement), indicating that additional partitioning was warranted, congruent with results from the pairwise tests. Several alternate management schemes were tested with only 2 plausible scenarios producing insignificant values for $F_{\mathrm{SC}}$. The lowest $F_{\mathrm{SC}}$ was achieved with 9 groupings that were tested with a second round of pairwise tests.

Haplotype data from the following sample sites were pooled for the second round of pairwise comparisons: CAP and OSS; CAN and MEL; JUN and FTL; CSL and DRT; ICZ and QRM; SGI and CSB. The 10 resulting North Atlantic regional clusters following sample site pooling were (1) South Carolina and Georgia (NRTH), (2) central eastern Florida (CEFL), (3) southeastern Florida (SEFL), (4) Cay Sal and Dry
Tortugas (DRSL), (5) Cuba (SWCB), (6) Isla Cozumel and mainland Quintana Roo beaches (QRMX), (7) southwestern Florida (SWFL), (8) central western Florida (CWFL), (9) northwestern Florida (NWFL), and (10) Cape Verde (CPVD). Haplotype frequencies for proposed management units were weighted based on the relative sizes of the rookeries comprising them (see Table S6 in the supplement). Comparisons among the proposed management units as well as Cuba and Cape Verde rookeries were all significant after sequential Bonferroni correction for multiple tests (Table 4, Table S7 in the supplement). Structure among proposed North Atlantic management units using both $380 \mathrm{bp}$ and $817 \mathrm{bp}$ control region sequences was strong $\left(F_{\mathrm{ST}}=0.182, \mathrm{p}<0.00001\right.$ [including Cuba]; $F_{\mathrm{ST}}=0.220, \mathrm{p}<0.00001$, respec- 
tively). When considering only straight-line distances among rookeries, there was evidence of isolation by distance $\left(\mathrm{r}^{2}=0.578, \mathrm{p}<0.00001\right)$, which accounted for approximately $33 \%$ of the observed genetic differentiation. However, when accounting for geographical barriers (primarily the Florida peninsula), this correlation was much weaker $\left(\mathrm{r}^{2}=0.382, \mathrm{p}=\right.$ 0.005 ) and accounted for only $14.5 \%$ of the genetic partitioning.

\section{DISCUSSION}

\section{Improved resolution through longer mtDNA sequences}

Expanding control region haplotypes from 380 to $817 \mathrm{bp}$ improved resolution of population structure at broad spatial scales for the CC-A1 lineage (Fig. 3). Polymorphism detected in analysis of the longer sequences increased differentiation between most of the proposed southeastern USA management units and Cape Verde, as was previously demonstrated for Georgia and Cape Verde comparisons (MonzónArgüello et al. 2010). This was particularly true for tests involving USA management units dominated by CC-A1.1. Similarly, CC-A1.4 was the dominant CC-A1 variant found in Mexican rookeries but was a minor haplotype in the USA and Cape Verde rookeries (Fig. 3). Increased differentiation was also detected between SEFL rookeries compared to all others in the southeastern USA. Haplotype CC-A1.3 accounted for a relatively large proportion of the CCA1 turtles sampled in southeastern Florida (31\%), whereas this haplotype accounted for only $0.4 \%$ and $0.7 \%$ of the CC-A1 turtles sampled nesting in central eastern (CAN and MEL) and central western (CSK) Florida, respectively, and was not detected in southwest Florida, northwest Florida, Georgia, or South Carolina.

Expanded control region sequences were comparatively less informative for the CC-A2 lineage. Variant CC-A2.1 has been recorded from all rookeries examined with longer sequences where CC-A2 is present (Garofalo et al. 2009, Monzón-Argüello et al. 2010, Yilmaz et al. 2011, Saied et al. 2012), and only modest partitioning of variants occurred among Northwest Atlantic rookeries. The Quintana Roo management unit was the most distinctive compared to all others, with CC-A2.3 and CC-A2.5 representing approximately $20 \%$ of the CC-A2 turtles sampled. CC-A2.4 was detected only among a portion of Florida rookeries but comprised a small proportion of the $\mathrm{CC}-\mathrm{A} 2$ individuals even in the region where it was most common (SEFL, 6\%).

Mitochondrial markers outside of the original control region read lengths have proven useful for improved stock resolution in other marine turtle species. Longer control region sequences subdivided 490 bp CM-A5 into 2 variants and demonstrated the demographic independence of the Aves Island green turtle rookery relative to others in the Caribbean (Shamblin et al. 2012). Expanded control region sequences have demonstrated increased structure among wider Caribbean hawksbill turtle rookeries through subdivision of 1 of 2 common 384 bp haplotypes (Haplotype F is now subdivided into Ei-A9 and Ei-A11; Velez-Zuazo et al. 2008, Browne et al. 2010, LeRoux et al. in press). However, longer sequences did not significantly improve resolution for haplotype A with nearly all foraging and nesting individuals still confounded as haplotype Ei-A1 (Browne et al. 2010, LeRoux et al. in press). The repetitive element present in the mitochondrial genome was recently shown to be highly polymorphic in Mediterranean green turtles (Tikochinski et al. 2012) and loggerhead turtles nesting at Zakynthos, Greece (Drosopoulou et al. 2012), despite minimal haplotype diversity in the remainder of the control region within nesting populations, suggesting that these may be suitable markers for identifying fine scale structure. Mitogenomic variable positions were also recently shown to improve stock structure among green turtle rookeries through subdivision of a common control region haplotype into regional subhaplotypes (Shamblin et al. 2012). Whereas it is difficult to predict precisely which species, populations, or lineages of marine turtles will benefit most from population level reanalysis based on deeper mitogenomic sequencing, these examples demonstrate that meaningful gains in resolution are possible.

\section{Phylogeography}

Initial restriction fragment length polymorphism analysis of the mitochondrial genome detected 2 lineages of loggerhead turtles globally, each represented by rookeries in the Indo-Pacific and Atlantic (Bowen et al. 1994). Bowen et al. (1994) hypothesized that one lineage may have evolved in the Atlantic (represented in the present study by CC-A1 and its related haplotypes), with a precursor to haplotype $\mathrm{F}$ (found at the Oman rookery in the Indian Ocean) invading that basin during an interglacial period around the southern tip of Africa. A logger- 
head injured while foraging in Kuwait was found to carry haplotype CC-A11 and was considered to be of Atlantic origin because this haplotype had previously been found in turtles foraging in the Atlantic (Al-Mohanna \& George 2010). However, given that the largest nesting population of loggerhead turtles in the Indo-Pacific occurs in Oman (Baldwin et al. 2003), it seems more likely that this turtle represents the proximate Oman rookery. Tag returns indicate that some portion of adult females nesting in Oman forage in the Arabian Gulf (Baldwin et al. 2003). Haplotype CC-A11 has been recorded at low frequency in 4 Atlantic rookeries (Quintana Roo, Cay Sal, Casey Key, and Cape Verde) and is represented by 3 expanded control region variants (MonzónArgüello et al. 2010, present study). These CC-A11 haplotypes are intermediate in the parsimony network between the clade containing CC-A2 and the CC-A1 variants. Should the Kuwaiti turtle indeed represent the Oman rookery, this suggests evolutionarily recent connectivity between North Atlantic and northwestern Indian Ocean loggerhead nesting populations.

The variable positions recovered provide sufficient resolution to propose a plausible colonization scenario for the CC-A1 lineage in the Atlantic, although refinements of phylogeographic inference must be tempered by the limited novel polymorphism detected in the expanded control region sequences. Cape Verde is the most equatorial of the large loggerhead turtle nesting aggregations in the Atlantic harboring CC-A1. Given the apparent derived position of CC-A1.1 relative to CC-A1.3 and CC-A1.4 in the haplotype network and the presence of CC-A1.3 and CC-A1.4 at both Cape Verde and western Atlantic rookeries (Fig. 2), Cape Verde may have served as a stepping-stone for the CC-A1 lineage that ultimately colonized the Mexican and southeastern USA coastlines. CC-A1.3 and CC-A1.4 were recorded in all 3 North Atlantic nesting aggregations examined, but CC-A1.1 was notably absent from Cape Verde and Quintana Roo rookeries (MonzónArgüello et al. 2010, present study). Thus, CC-A1.1 from southeastern USA rookeries is likely the most recently derived of the 3 common CC-A1 variants found in North Atlantic rookeries despite being the most common variant in the Atlantic with respect to numbers of nesting turtles. This unexpected pattern may have arisen as a result of the intensive harvest pressure exerted on the Cape Verde rookery over several centuries that has continued into recent times (López-Jurado et al. 2007). Recent abundance estimates suggest that the Cape Verde rookery is the third largest loggerhead turtle rookery globally despite considerable human take (Marco et al. 2012), and therefore may have once been vastly larger than at present. Short haplotype CC-A1 has also been reported at low frequency from Cuban rookeries (Ruiz et al. 2008). Expanded sequences were not available for the southwest Cuban nesting populations, so these rookeries cannot be excluded as a proximate source for the CC-A1 lineage that has colonized the entire southeastern USA coastline.

Bowen et al. (1994) and Encalada et al. (1998) hypothesized that the Mediterranean was colonized by CC-A2 of western Atlantic origin following the Wisconsin glaciation. Haplotype CC-A2.1 was the most common variant of CC-A2 detected in the Northwest Atlantic rookeries and the only variant recorded from Calabria, Italy (Garofalo et al. 2009) and Turkish rookeries (Yilmaz et al. 2011). Therefore expanded sequencing effort did not permit critical reexamination of previous phylogeographic scenarios. However, recent analysis of Libyan rookeries using the longer sequences detected a CC-A2 subhaplotype at high frequencies, demonstrating the demographic isolation of these rookeries relative to others in the Mediterranean (Saied et al. 2012). Deeper sequencing of the mitogenome is warranted to determine whether any diagnostic variable positions occur that will distinguish turtles of western Atlantic and Mediterranean origin. As the South African rookery shared restriction fragment length polymorphism haplotype D with Northwest Atlantic and Mediterranean rookeries (Bowen et al. 1994), sequence data are needed from the Natal rookery to resolve its relationship to those in the Atlantic.

The lowest haplotype diversity was recorded for the northernmost sampled rookeries (CAP, OSS), whereas the highest haplotype diversity occurred at the southernmost sampled rookery (QRM) in the Northwest Atlantic. This apparent latitudinal pattern was not present at finer spatial scales among peninsular Florida rookeries. Lack of haplotype diversity for CAP and OSS is consistent with a hypothesized population bottleneck that occurred during colonization of these beaches following the most recent glacial maximum (Encalada et al. 1998). Low haplotype diversity recorded for DRT and CSL may also reflect recent colonization. These low elevation islands are situated in close proximity to major surface currents (Hine \& Steinmetz 1984, Fratantoni et al. 1998) and likely represent highly dynamic nesting habitats over ecological time scales. QRM exhibited the highest haplotype diversity recorded for any loggerhead rookery described to date, and represents the most 
tropical of the Northwest Atlantic rookeries sampled in the present study. The Caribbean coast of Mexico may therefore host the oldest extant rookery in the region, possibly serving as the source for the CC-A2 lineage that colonized the Florida coast and the Mediterranean.

\section{Population structure}

Larger sample sizes collected across multiple nesting seasons provided additional support for the latitudinal genetic break across central Florida inferred from previous analysis (Shamblin et al. 2011a). Haplotype frequency transitions were detected between central and southern sample sites along both coasts of Florida. Moreover, the expanded dataset indicated that southernmost sampled rookeries along the Gulf and Atlantic coasts of the Florida peninsula were genetically distinct. These rookeries were not significantly different in a previous analysis based on smaller sample sizes, but it was postulated that they were demographically isolated given the discontinuity of available nesting habitat around the southern tip of the Florida peninsula and the scarcity of recorded exchange of nesting females between west coast and east coast Florida rookeries (Shamblin et al. 2011a). The differentiation evident through larger sample sizes and polymorphisms within the longer control region sequences also now suggest that an earlier hypothesis of female straying to nest at nonnatal sites at similar latitudes across the axis of the Florida peninsula (Shamblin et al. 2011a) may be less plausible.

Patterns of differentiation were not always clearly associated with geographic distance. Though isolation by distance was detected in this study, it explained only $15 \%$ of the genetic partitioning when accounting for terrestrial barriers, consistent with Australasian green turtle rookeries spanning a similar spatial scale (Dethmers et al. 2006). The weakest statistically significant differentiation occurred between CSK and MEL, on opposite sides of the Florida peninsula. CSK and KEY were the proximal sample sites that exhibited the weakest, though still significant, genetic differentiation $\left(817 \mathrm{bp} F_{\mathrm{ST}}=0.018, \mathrm{p}=\right.$ 0.0002 ) and were separated by approximately 160 beach $\mathrm{km}$. The strongest differentiation detected among proximal mainland rookeries occurred between MEL and JUN, separated by approximately $135 \mathrm{~km}\left(817 \mathrm{bp} F_{\mathrm{ST}}=0.209, \mathrm{p}<0.00001\right)$. Yet the rookeries of CAN and MEL, separated by 100 beach $\mathrm{km}$, did not exhibit significantly different haplotype frequencies (817 bp $\left.F_{\mathrm{ST}}=0.002, \mathrm{p}=0.16406\right)$. These data indicate that a standard geographical yardstick for predicting where genetic differentiation might occur at finer spatial scales cannot be applied within the region and possibly elsewhere where loggerhead turtles nest. This conclusion is consistent with Caribbean hawksbill turtle studies that indicate structure at scales as fine as $25 \mathrm{~km}$ (leeward and windward Barbados rookeries, Browne et al. 2010) and yet lack of differentiation between some regional rookeries separated by several hundred km (United States Virgin Islands and windward Barbados, LeRoux et al. in press). Similarly, the finest scale structure detected among Australasian green turtle rookeries occurred at $<300 \mathrm{~km}$ (Philippine and Malaysian Turtle Islands), whereas the rookeries along the North West Shelf of Australia separated by over $1000 \mathrm{~km}$ could not be distinguished (Dethmers et al. 2006). Nonetheless, the overall pattern detected for loggerhead turtles in the present study suggests that rookeries separated by $150 \mathrm{~km}$ or more are likely demographically isolated despite a lack of detectable genetic differentiation. Such rookeries should therefore be conservatively treated as distinct management units unless alternative methods demonstrate significant demographic connectivity.

Factors driving and maintaining the strong genetic break that occurs between Melbourne Beach and Juno Beach are unclear. Beaches in this region form essentially continuous nesting habitat and host the vast majority of loggerhead nesting in the state of Florida (NMFS \& USFWS 2008). However, nesting densities do vary significantly with peaks occurring in southern Brevard County to the north and Martin and northern Palm Beach Counties to the south with a relative trough in nesting density occurring along the intervening beaches in Indian River and St. Lucie Counties (Witherington et al. 2009). A similar pattern in relative nesting densities also occurs in green turtles that share these beaches for nesting (Florida Fish and Wildlife Conservation Commission, FWC, Statewide Nesting Beach Survey data). At a regional scale within the southeastern USA, distance from the Gulf Stream System accounted for approximately $90 \%$ of the variance in nest abundance, prompting the hypothesis that post-hatchling mortality during the swim frenzy in combination with natal homing may be a major driver of nesting density (Putman et al. 2010). However, this correlation was weaker in finer scale analyses conducted at the county level in Florida, suggesting complex local factors, including coastal geomorphology, likely contribute to the observed nesting density patterns (Putman et al. 
2010). Relative nest densities vary spatially at fine scales across these beaches but are remarkably conserved over a long time series comprised of mixed cohorts of nesting females each year (Witherington et al. 2009), also suggesting that fine scale nest site selection based on local cues is shaping the peaks and valleys in the nesting density distribution and may contribute to the observed genetic partitioning. Further research into potential factors shaping this genetic break is warranted.

The loggerhead rookeries of Mexico's Caribbean coast are genetically distinct from those of the southeastern United States. This partitioning was evident in prior analysis based on smaller sample sizes and $380 \mathrm{bp}$ haplotypes (Encalada et al. 1998). However, increased sampling effort yielded additional haplotypes and demonstrated that several haplotypes previously believed to be endemic to the Florida and Cuban rookeries also occur in Quintana Roo. Haplotype CC-A1 was not previously detected in the Mexican nesting population (Encalada et al. 1998), but accounted for $\sim 8 \%$ of females sampled in the present study. CC-A1.4, the most common CC-A1 variant in Quintana Roo, accounted for only $\sim 3 \%$ of CC-A1 females sampled in the southeastern United States nesting aggregation, providing further evidence of demographic partitioning between the rookeries of Mexico's Caribbean coast and those of Florida.

Analysis based on published 380 bp haplotypes from southwestern Cuban rookeries supports recognition of a discrete Cuban management unit, consistent with earlier recommendations generated from comparisons based on smaller sample sizes from the southeastern United States and Mexico (Ruiz et al. 2008). Though that study did not detect any structure among the 4 rookeries examined in Cuba (Guanahacibibes Peninsula, San Felipe Cays, Isla de Juventud, and Cayo Largo del Sur), haplotype frequencies hint that Cuba may in fact host multiple demographically partitioned nesting populations. Larger sample sizes and deeper sequencing are needed for more robust inferences regarding genetic structure among Cuban rookeries and to better characterize their relationship with other loggerhead turtle rookeries in the region.

Lack of haplotype frequency differentiation between CSL and DRT rookeries may reflect historical genetic signature rather than contemporary demographic connectivity. Both rookeries were dominated by haplotype CC-A2.1 (86\% of SAL and $90 \%$ of DRT), potentially limiting the power to distinguish them. Haplotype frequencies for DRT were significantly different from $\operatorname{KEY}\left(F_{\mathrm{ST}}=0.309, \mathrm{p}<0.00001\right)$, the closest mainland rookery analyzed, approximately $200 \mathrm{~km}$ distant from DRT. DRT and SAL are separated by $270 \mathrm{~km}$, suggesting that these insular rookeries may not be connected through demographically relevant levels of female exchange. We therefore recommend that they be treated as distinct management units unless and until other data sources indicate significant demographic connectivity between these rookeries.

Similarly, OSS and CAP were fixed for haplotype CC-A1.1 despite $200 \mathrm{~km}$ of separation, thus lack of diversity of the genetic marker prevents robust assessment of demographic connectivity among rookeries grouped within the northern management unit. Given the levels of differentiation apparent along the Florida coastline, it is likely that some level of demographic partitioning occurs among the northern management unit rookeries from northeastern Florida through Virginia, as previously hypothesized (Encalada et al. 1998). However, in this case, these rookeries occur along a continental coastline that supports essentially continuous low density nesting by loggerhead turtles. It is therefore impossible to recommend appropriate boundaries without additional data. Future research should reevaluate the relationship of the northern management unit rookeries through analysis of larger sample sizes, deeper mitogenomic sequencing, and demographic studies.

Analyses of $380 \mathrm{bp}$ and $817 \mathrm{bp}$ haplotype frequencies based on expanded sampling effort support the recognition of 9 loggerhead turtle management units in the Northwest Atlantic corresponding to the beaches of (1) South Carolina and Georgia, (2) central eastern Florida, (3) southeastern Florida, (4) Cay Sal, Bahamas and Dry Tortugas, Florida, (5) southwestern Cuba, (6) Quintana Roo, Mexico, (7) southwestern Florida, (8) central western Florida, and (9) northwestern Florida. Geographic considerations warrant separate treatment for the Cay Sal and Dry Tortugas rookeries, bringing the total to 10 management units in the Northwest Atlantic. Delimiting precise boundaries among southeastern USA management units requires more extensive geographic sampling to fill in the gaps between study sites. Continued use of the longer sequences is justified for defining rookeries in a broader context, even if they fail to substantially improve resolution of population structure at finer spatial scales. Given the increase in resolution of the $\mathrm{CC}$-A1 lineage realized with expanded control region sequences, mitogenomic sequencing may further elucidate population structure in this vagile marine species. 
Acknowledgements. In addition to the many volunteers, students, and staff representing the authors' institutions, we thank S. Ouellette and the Broward County Sea Turtle Program crew, B. Drye of the St. George Island volunteer turtlers, and R. Chacón, director of the marine turtle program in the municipality of Cozumel, México for providing samples. We thank G. Clark at the ICBR Genetic Analysis Laboratory at the University of Florida for isolations and amplifications and S. Shankar in the ICBR Genomics Core at the University of Florida for sequencing a portion of the Florida samples. We also recognize contributions from A. Meylan, S. Murphy, D. Griffin, A. McKee, S. Dawsey, D. Browning, A. Mackinnon, M. Koperski, A. Frey, and K. Stewart. Thanks to 4 anonymous reviewers who greatly improved the quality of the manuscript. This research was funded in part by a grant awarded from the Sea Turtle Grants Program. The Sea Turtle Grants Program is funded from proceeds from the sale of the Florida Sea Turtle License Plate. Learn more at www.helpingseaturtles.org.

\section{LITERATURE CITED}

Abreu-Grobois A, Horrocks J, Formia A, Dutton P and others (2006) New mtDNA dloop primers which work for a variety of marine turtle species may increase the resolution of mixed stock analyses. In: Frick M, Panagopoulou A, Rees AF, Williams K (eds) Book of abstracts from the 26th annual symposium on sea turtle biology and conservation. International Sea Turtle Society, Athens, p 179

Addison D, Mumford B (1996) Sea turtle nesting activity on the Cay Sal Bank. Bahamas J Sci 3:31-36

Al-Mohanna S, George P (2010) Assessment of the origin of a loggerhead turtle, Caretta caretta, found in Kuwaiti waters, using mitochondrial DNA. Zool Middle East 49: 39-44

Baldwin R, Hughes G, Prince R (2003) Loggerhead turtles in the Indian Ocean. In: Bolten A, Witherington B (eds) Loggerhead sea turtles. Smithsonian Institution Press, Washington, DC, p 218-232

> Benhamou S, Sudre J, Bourjea J, Ciccione S, De Santis A, Luschi P (2011) The role of geomagnetic cues in green turtle open sea navigation. PLoS ONE 6:e26672

Bolker BM, Okuyama T, Bjorndal KA, Bolten AB (2007) Incorporating multiple mixed stocks in mixed stock analysis: 'many to many' analyses. Mol Ecol 16:685-695

Bolten AB (2003) The loggerhead sea turtle: a most excellent fishe. In: Bolten AB, Witherington BE (eds) Loggerhead sea turtles. Smithsonian Institution Press, Washington, DC, p 1-3

> Bowen BW, Karl SA (2007) Population genetics and phylogeography of sea turtles. Mol Ecol 16:4886-4907

> Bowen BW, Avise JC, Richardson JI, Meylan AB, Margaritoulis D, Hopkins-Murphy SR (1993) Population structure of loggerhead turtles (Caretta caretta) in the northwestern Atlantic Ocean and Mediterranean Sea. Conserv Biol 7:834-844

> Bowen BW, Kamezaki N, Limpus CJ, Hughes GR, Meylan AB, Avise JC (1994) Global phylogeography of the loggerhead turtle (Caretta caretta) as indicated by mitochondrial DNA haplotypes. Evolution 48:1820-1828

Bowen BW, Bass AL, Chow SM, Bostrom M and others (2004) Natal homing in juvenile loggerhead turtles (Caretta caretta). Mol Ecol 13:3797-3808

Bowen BW, Bass AL, Soares L, Toonen RJ (2005) Conserva- tion implications of complex population structure: Lessons from the loggerhead turtle (Caretta caretta). Mol Ecol 14:2389-2402

Browne DC, Horrocks JA, Abreu-Grobois FA (2010) Population subdivision in hawksbill turtles nesting on Barbados, West Indies, determined from mitochondrial DNA control region sequences. Conserv Genet 11:1541-1546

Carreras C, Pont S, Maffucci F, Pascual M and others (2006) Genetic structuring of immature loggerhead sea turtles (Caretta caretta) in the Mediterranean sea reflects water circulation patterns. Mar Biol 149:1269-1279

- Carreras C, Pascual M, Cardona L, Aguilar A and others (2007) The genetic structure of the loggerhead sea turtle (Caretta caretta) in the Mediterranean as revealed by nuclear and mitochondrial DNA and its conservation implications. Conserv Genet 8:761-775

> Chaieb O, El Ouaer A, Maffucci F, Bradai M, Bentivegna F, Said K, Chatti N (2010) Genetic survey of loggerhead turtle Caretta caretta nesting population in Tunisia. Mar Biodiversity Rec 3:e20

> Clement M, Posada D, Crandall K (2000) TCS: A computer program to estimate gene genealogies. Mol Ecol 9: 1657-1659

Dethmers KEM, Broderick D, Moritz C, FitzSimmons NN and others (2006) The genetic structure of Australasian green turtles (Chelonia mydas): exploring the geographical scale of genetic exchange. Mol Ecol 15:3931-3946

Dodd CK Jr (1988) Synopsis of the biological data on the loggerhead sea turtle Caretta caretta (Linnaeus 1758). US Fish and Wildlife Service Biological Report 88 (14)

Dow W, Eckert K, Palmer M, Kramer P (2007) An atlas of sea turtle nesting habitat for the wider Caribbean region. Wider Caribbean Sea Turtle Network and The Nature Conservancy. WIDECAST Technical Report 6

> Drosopoulou E, Tsiamis G, Mavropoulou M, Vittas S and others (2012) The complete mitochondrial genome of the loggerhead turtle Caretta caretta (Testudines: Cheloniidae): genome description and phylogenic considerations. Mitochondrial DNA 23:1-12

Dutton PH (1996) Methods for collection and preservation of samples for sea turtle genetics studies. In: Bowen BW, Witzell WN (eds) Proc Int Symp Sea Turtle Conservation Genetics. NOAA Technical Memorandum NMFSSEFSC-396, p17-24

> Encalada SE, Bjorndal KA, Bolten AB, Zurita JC and others (1998) Population structure of loggerhead turtle (Caretta caretta) nesting colonies in the Atlantic and Mediterranean as inferred from mitochondrial DNA control region sequences. Mar Biol 130:567-575

- Excoffier L, Lischer HEL (2010) Arlequin suite ver 3.5: A new series of programs to perform population genetics analyses under Linux and Windows. Mol Ecol Resour 10: $564-567$

Fratantoni PS, Lee TN, Podesta GP, Muller-Karger FE (1998) The influence of Loop Current perturbations on the formation and evolution of the Tortugas eddies in the southern Straits of Florida. J Geophys Res 103:24759-24779

Garofalo L, Mingozzi T, Micó A, Novelletto A (2009) Loggerhead turtle (Caretta caretta) matrilines in the Mediterranean: Further evidence of genetic diversity and connectivity. Mar Biol 156:2085-2095

Hamann M, Godfrey MH, Seminoff JA, Arthur K and others (2010) Global research priorities for sea turtles: informing management and conservation in the 21 st century. Endang Species Res 11:245-269 
Hine AC, Steinmetz JC (1984) Cay Sal Bank, Bahamas - a partially drowned carbonate platform. Mar Geol 59: 135-164

Laurent L, Casale P, Bradai MN, Godley BJ and others (1998) Molecular resolution of marine turtle stock composition in fishery bycatch: A case study in the Mediterranean. Mol Ecol 7:1529-1542

LeRoux R, Dutton P, Abreu-Grobois A, Lagueux C and others (in press) Re-examination of population structure and phylogeography of hawksbill turtles in the Wider Caribbean using longer mtDNA sequences. J Hered doi: 10.1093/jhered/ess055

> Lohmann KJ, Luschi P, Hays GC (2008a) Goal navigation and island-finding in sea turtles. J Exp Mar Biol Ecol 356: 83-95

Lohmann KJ, Putman NF, Lohmann CMF (2008b) Geomagnetic imprinting: A unifying hypothesis for long-distance natal homing in salmon and sea turtles. Proc Natl Acad Sci USA 105:19096-19101

López-Jurado LF, Sanz P, Abella E (2007) Loggerhead nesting on Boa Vista, República de Cabo Verde. SWOT Report 2

Mantel N (1967) The detection of disease clustering and a generalized regression approach. Cancer Res 27:209-220

Marco A, Abella E, Liria-Loza A, Martins S and others (2012) Abundance and exploitation of loggerhead turtles nesting in Boa Vista Island, Cape Verde, the only substantial rookery in the eastern Atlantic. Anim Conserv 15: $351-360$

Monzón-Argüello C, Rico C, Naro-Maciel E, Varo-Cruz N, López P, Marco A, López-Jurado LF (2010) Population structure and conservation implications for the loggerhead sea turtle of the Cape Verde islands. Conserv Genet 11:1871-1884

NMFS, USFWS (National Marine Fisheries Service, US Fish and Wildlife Service) (2008) Recovery plan for the Northwest Atlantic population of the loggerhead sea turtle (Caretta caretta), 2nd revision. National Marine Fisheries Service, Silver Spring, MD

Pearce AF (2001) Contrasting population structure of the loggerhead turtle (Caretta caretta) using mitochondrial and nuclear DNA markers. MSc thesis, University of Florida, Gainesville, FL

Putman NF, Bane JM, Lohmann KJ (2010) Sea turtle nesting distributions and oceanographic constraints on hatchling migration. Proc Biol Sci 277:3631-3637

Raymond M, Rousset F (1995) An exact test for population differentiation. Evolution 49:1280-1283

Reis E, Soares LS, Vargas S, Santos F and others (2010) Genetic composition, population structure and phylogeography of the loggerhead sea turtle: Colonization hypothesis for the Brazilian rookeries. Conserv Genet 11: 1467-1477

Editorial responsibility: Philippe Borsa, Montpellier, France
Revelles M, Carreras C, Cardona L, Marco A and others (2007) Evidence for an asymmetrical size exchange of loggerhead sea turtles between the Mediterranean and the Atlantic through the straits of Gibraltar. J Exp Mar Biol Ecol 349:261-271

Rice WR (1989) Analyzing tables of statistical tests. Evolution 43:223-225

Ruiz A, Vega M, Riverón F, Abreu F and others (2008) Estructura genética de poblaciones de Caretta caretta en el gran Caribe y la costa Atlántica de Estados Unidos, con enfasis en colonias de anidacion del suroeste Cubano. Rev Invest Mar 29:151-160

Saied A, Maffucci F, Hochscheid S, Dryag S and others (2012) Loggerhead turtles nesting in Libya: an important management unit for the Mediterranean stock. Mar Ecol Prog Ser 450:207-218

Shamblin BM, Faircloth BC, Dodd M, Wood-Jones A and others (2007) Tetranucleotide microsatellites from the loggerhead sea turtle (Caretta caretta). Mol Ecol Notes 7 : 784-787

Shamblin BM, Faircloth BC, Dodd MG, Bagley DA and others (2009) Tetranucleotide markers from the loggerhead sea turtle (Caretta caretta) and their cross-amplification in other marine turtle species. Conserv Genet 10: $577-580$

> Shamblin BM, Dodd MG, Bagley DA, Ehrhart LM and others (2011a) Genetic structure of the southeastern United States loggerhead turtle nesting aggregation: Evidence of additional structure within the peninsular Florida recovery unit. Mar Biol 158:571-587

Shamblin BM, Dodd MG, Williams KL, Frick MG, Bell R, Nairn CJ (2011b) Loggerhead turtle eggshells as a source of maternal nuclear genomic DNA for population genetic studies. Mol Ecol Resour 11:110-115

Shamblin BM, Bjorndal KA, Bolten AB, Hillis-Starr ZM and others (2012) Mitogenomic sequences better resolve stock structure of southern Greater Caribbean green turtle rookeries. Mol Ecol 21:2330-2340

Tikochinski Y, Bendelac R, Barash A, Daya A, Levy Y, Friedmann A (2012) Mitochondrial DNA STR analysis as a tool for studying the green sea turtle (Chelonia mydas) populations: the Mediterranean Sea case study. Mar Genomics 6:17-24

Velez-Zuazo X, Ramos WD, Van Dam RP, Diez CE, AbreuGrobois A, McMillan WO (2008) Dispersal, recruitment and migratory behaviour in a hawksbill sea turtle aggregation. Mol Ecol 17:839-853

> Witherington B, Kubilis P, Brost B, Meylan A (2009) Decreasing annual nest counts in a globally important loggerhead sea turtle population. Ecol Appl 19:30-54

> Yilmaz C, Turkozan O, Bardakci F (2011) Genetic structure of loggerhead turtle (Caretta caretta) populations in Turkey. Biochem Syst Ecol 39:266

Submitted: February 27, 2012; Accepted: August 1, 2012 Proofs received from author(s): November 13, 2012 